Viewpoints and Letters to the Editor are published in Hort- comments on matters of concern to horticulturists. These are Science to provide members of the American Society for Hor- not statements of official Society policy nor do they necessarticultural Science an opportunity to share their experiences and ily reflect the views of a majority of the Society's members.

\title{
The Corporate University: A Place with Few Values and No Soul Presidential Address ${ }^{1}$
}

\author{
George C. Martin² \\ ASHS President, 1989-90
}

The university describes itself to the general public as a mature educational system that nurtures and encourages freedom of inquiry, independent thinking, scholarship, intellectual development, and exploration. It says it provides the atmosphere for innovative action. Certainly, I expected these grand attributes of a university when I became a university professor. But to my dismay, I have found that the university workplace falls far short of its communicated advertisement, providing, at best, an above-average intellectual environment. Nor does the university tolerate-let alone nurture-ideas or explorations that run counter to the carefully defined objectives set by granting and funding agencies like federal and state governments, private business concerns, and local agricultural interests.

When I entered academia, I expected that, among other things, I would find science professors interested and conversant in the humanities and literature. I thought then that a science faculty with broad interests and developing knowledge was prerequisite for the university to fulfill its responsibility of educating our youth in a manner that would infuse quality into their lives and our society. Instead, what have I found? Whether in the science of horticulture or biochemistry, I have found that we have been trained as technicians-not scholars. In horticulture we have been trained well to make plants behave in a proscribed fashion. Yet we have had little training in skills required to explore how and why plants, people, and our surroundings work. The university does not expect faculty lacking a broad education to acquire that breadth on their own. Rather, we are accelerating our efforts to turn out technicians, a process most evident in graduate education, where we train super technicians. The depressing fact remains that young professors who are thinkers, intellectual explorers, and innovative scientists will not fit well into our Corporate Universities.

Gradually and steadily, our American society has adopted an expectation of immediate gratification in daily life, an emphasis

${ }^{1}$ Presented at the 87th Annual Meeting of the American Society for Horticultural Science, Tucson, Ariz., on 7 Nov. 1990.

${ }^{2}$ Dept. of Pomology, Univ. of California, Davis.

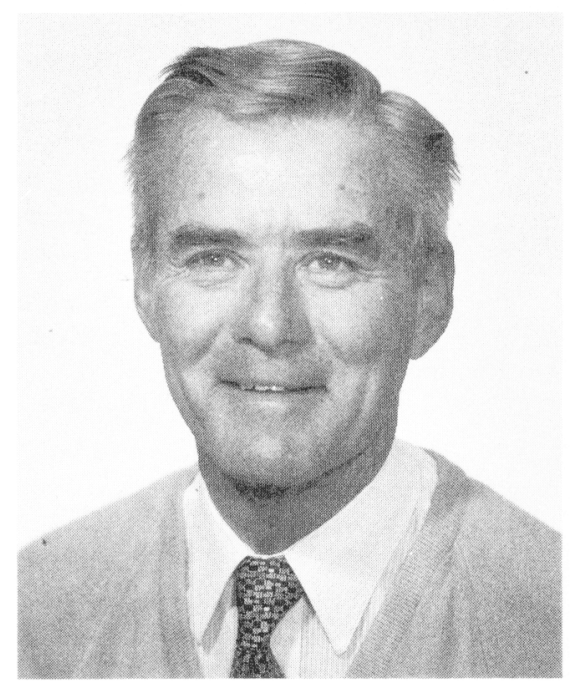

that has weakened the fundamental base of industrial manufacturing, stability in the business world in general, and the long-term value of our university system in particular. Continual renewal and invigoration of life's enterprises stem from asking questions that demand re-evaluation of fundamental processes and the results of which do not guarantee immediate gratification.

This short-term view has influenced the university as it directs the process of professorial inquiry. In the past, in those universities where sufficient research funds accompanied faculty positions, investigations were marked by their rich diversity. As grant funding policy has taken over, however, we faculty have, for survival, adapted research investigations to qualify for support as described by the special interest of the granting agency. Here, the driving force is usually problem solving rather than research, and the problem solving has a short-term payoff. Problem solving is driven by making something work; research is driven by understanding how it works.

Sufficient grant funds are not available to all researchers, as fewer than $20 \%$ of applicants for these funds are successful. Most fields of study do not qualify for grants, and those professors whose research does not qualify for a grant languish without sufficient research support. Thus, faculty are hired to accomplish work for which little or no resource is available, resulting in a curious dilemma: talent and knowledge for sale, but no buyers.

I believe the university can and must live up to its advertisement to the public. I am writing this piece to describe, in my terms, what a professor and university could be. If in the reading of this material you are personally affronted, disagree or agree with the content, then I challenge you to act. As professors and students, we are part of the problem I describe and the major part of the solution. The very nature and importance of the subject matter result on my part, in pontification, simplification, and generalization. Recognizing this condition of mind, I have tried to develop this piece with clarity, the openly expressed passion of a whole man and all of his weaknesses, and with the fundamental desire to leave this profession better off than I found it.

A university is an institution delicately poised between the relentless demands of the marketplace and the dreams of a society attempting to snatch a taste of honey along the road of life. The university in its short existence of some 900 years has rarely known both viability and stability at the same moment. When viable, the university should be a source of disturbing ideas. When intellectually serene, certainly the university is dormant. And at the present time, I believe the university is moving toward dormancy.

The current university can be accurately labeled the Corporate University. In typical land-grant universities, boards of regents appoint administrators who set policies reflecting the corporate mentality of the regents. Governors appoint the regents and corporations make contributions to governor's campaigns. Such universities have structures that are not much different from many business corporations in the American marketplace. The Corporate University is a place with few values and no soul.

Knowledge is the currency of the Corporate University. Knowledge is power. But of what long-term redeeming value is knowledge without wisdom? A Japanese proverb likens knowledge without wisdom to an ass carrying a pack of books. The Corporate University is a place where technicians both churn out knowledge for sale and clone more technicians for the marketplace. But this is knowledge without wisdom, and these technicians lack questioning minds. Wisdom is 
not the common coinage of the Corporate University nor of the marketplace. The questioning mind has no value in a system where the saleable, disposable product is the altar for success.

I do not contend that our Corporate University is at a crossroads or that we face a terminal crisis. Rather, I believe that the university, in these changing times, enjoys opportunities that have been rarely available before. Change is more readily accomplished during periods of indecision and poor leadership, when the public has lost faith in their institutions. Our society's institutions, including universities, are at that point now. The university has drifted into its corporate stance, and the faculty has aided and abetted the change.

The university has arrived at this juncture for varied and complex reasons. Part of the problem stems from the individuals whom the faculty have chosen to serve as administrators and who are ultimately appointed by the regents. Too often these servants have been selected from among those faculty who have lost interest in teaching and research, or who were more interested in management than in teaching and research, No matter in which direction we cast blame, the public no longer trusts the university or its professors, and the real problem lies not with the administrators but with the professors who make up the faculty. Commonly, threats to institutions occur from without, but in the case of the Corporate University the fault lies within. The faculty has shot itself in the foot.

The myriad complex events leading to the Corporate University have occurred with faculty approval and by faculty instigation. We faculty continue to be part of the problem and we faculty are part of the solution. In America, the Corporate University has evolved over the last 100 years. The change has been particularly evident in the last 30 years, when technical services from the university have been more and more for sale in the marketplace.

\section{Purpose and discussion format}

So far, I have focused my comments on the land-grant universities, but my intent is to include private universities as well. We need both systems and both need "fixing." My indictment is that the land-grant universities have abandoned their mission, that the faculty of these universities may not know of nor agree with the land-grant mission, that grant funding has moved its focus from society's problems to those of the government or of narrowly defined private agencies, and that tenure criteria are misdirected. Tenure criteria should not be based on the ability to acquire grants; rather, they should involve evidence for critical thinking, for excellence in scholarship, and for prospective advancement in the chosen field of study.

Although the language I am using is direct and laconic, my purpose is not to condemn, nor is it to name names or blame blames nor to argue either/or. Rather, I am arguing for a balance. My purpose is to describe a pos- itive view of the complex problems facing the land-grant university and to offer solutions.

The Land Grant of 1862 underpinned America's successful thrust into the 20th Century, but that system will not necessarily fit America's needs for the 21st Century. In fact, I believe universities are now meeting past needs and that as a result we are poorly adapted to the current and future needs of our society. The university should have educated people to prepare our society for a graceful change from the needs of a war economy to a peace-time economy, but it has not. We did not anticipate the 1990 eventualities; we were not prepared. We must look beyond training technicians for welldefined jobs and instead educate students to adapt to diversity and to yet-to-be defined jobs. The student of today must be educated broadly at the university and must learn specific job skills at the place of employment.

Given its most expansive interpretation, our future is one of global change. Diversity will be the rule in the future; change will be as common as life's problems are complex. It is not currently possible to forecast a career, nor will it be so in the future. Yet we can be sure that the individual's career will be marked by unknown diversity, the necessity for adapting to change, and the opportunity to create change.

At a time of such diversity and change, when technical skills are at a premium on the marketplace, I advocate that the university should place more emphasis on classical education. The structure of this classical education should emphasize the underlying bases and theories for all things and place less emphasis on technical training that can be obtained in other educational systems or on the job. This classical education should stress written and verbal skills; computation, risk assessment, and probability cognizance; social skills and management techniques; history and our role in making history; philosophy and the struggle to understand life's great questions of why we are here and where are we going; the environment and the interrelation of all things; the challenge to make a difference, to leave a place in a better state than when we arrived; and the study of, and the attempt to live, an ethical life. A classical education should be done in clear view of the business world, and as a requirement for graduation, an internship in the business world might be required.

America's leaders come from universityeducated sources, and when a society becomes specialized its leaders must have the broadest education. Leadership lacking this broad education will fail to perceive the ramifications of exploitation that comes from overspecialization. They will not comprehend the necessity for nor know how to achieve integration in our complex society. I believe our leaders now reflect narrow, special interests. They fail to comprehend the essence of requirements that make up a great society. Coupled with this overemphasis in specialization in our educational process is the chilling shortcoming that has led to our intellectuals' becoming scientific illiterates.

To consummate this reform of the Corporate University, the land-grant university, there should be a sense of identity in education. The university should have a dream; it should be a place both of contention and aspiration. It should be a template for the future of our society. To continue in the Corporate University means that we are just one more common institution in the marketplace, where education competes with poverty, health, environmental pollution, and the weapons of war research dollars.

To understand our current situation, we must know and understand our past. Toward that end, I will provide a brief review of the history of the university. This will reveal the strict, inflexible culture in which the university was born and in which it has evolved. Then I will discuss the concept of academic freedom, the most cherished and fragile part of a university, and perhaps the greatest loss we currently face. Next I will describe my view of our current land-grant universitythe Corporate University. Here, a strong personal bias is evident, as I believe we are now meeting past needs and that we are doing so in a manner detrimental to our students and to our future. Next, I will describe a new university, with a structure in which classical education will receive emphasis. Then I will articulate the notion of forming The University, a private and unshackled university, as it might be. I will call for our American society to rekindle their faith in education, so that they will freely support a few institutions that qualify as, "The University". And in the epilogue I will deal with dreams vs. reality, that is, I will explore what can be done. The current "players" in the Corporate University like to speak of reality, but of which reality do they speak? I will pursue the reality of education, one that is far from the current consensus but one that aims to restore a sense of mission and integrity.

These same "players" speak of openness, but their openness is one in which values do not exist, an openness that is empty, a "gowith-the-flow" mentality. It is the openness of the marketplace. The openness I argue for is based on firm standards, for openness without standards or conviction is meaningless. The university must have an attitude of undefensive openness. With such an attitude, change occurs by persuasive pedagogic arguments surrounding research and education. The compelling arguments in the university of my choice would not be based on the influence of dollars gained in the marketplace. Rather, argumentation would embody values, promote discovery, and reveal truths that peel back the layers of human ignorance.

\section{EVOLUTION OF THE UNIVERSITY Its beginning}

Where do we place those beginning forces that formed the notion of an organized university? There were Greek and Roman schools predating the birth of Jesus Christ. In his activities, Christ challenged the religious in- 
stitutions of that day, which used knowledge as a weapon of mental slavery over its peoples. As an institution, the university as we know it took as its model the centers of learning that grew up around the great mosques of Baghdad, Cordoba, and Cairo. As the sparks leading to the Renaissance were being struck, the monastic movement passed through the Carolinian schools of France, Palestine, and Italy. Professional schools also emerged, with medicine at Salarno and Roman law at Bologna. By the 12th Century, the lecture rooms of Paris were teeming with thousands of students who flocked to hear Abelard, William of Champeaux, and Roselin. The earliest records are a patchwork of many missing pages.

Winchester (1986) suggests we know most about the medieval universities of Paris and Oxford. He lists four features of those universities that are similar to our own: 1) They are largely immune from the interference by the surrounding civil order, and sometimes they actually dominate that order; 2) they are international in scope; 3 ) they have a faculty and student body that reside nearby and often within the university precincts; and 4) the university is internally organized into hierarchial and systematic educational machinery; usually a faculty of arts and higher faculties, including theology, law, and medicine (at least). One might argue about these parallels in specific cases, but they seem to at least reflect the current perception of our modern university.

Those European beginnings and the precepts listed above carried into the New World. The European universities were religious in emphasis and Latin in language. They were exclusive, and the openness I call for did not exist. Primarily, only wealthy males were privileged to attend. They taught the past and resisted change. The colleges formed in America were the result of royal charters from Britain and colonial charters. These fledgling colleges eventually became universities, collections of colleges. Their curricula included Greek, Latin, grammar, rhetoric, mathematics, and philosophy. Many churches held sway over all aspects of these colleges. Discipline was rigid, and individual expression by students or faculty was not condoned. The extent of such control was revealed by Cornell's first president, Andrew White, who was quoted as saying that the American college before 1862 was "as stagnant as a Spanish convent and as selfsatisfied as a Bourbon duchy" (Rogers, 1942). It is amusing to contemplate how appropriate that quote seems for certain segments of our university today.

\section{The American university}

The contrast between the European university and the emerging American university of the 19th Century is particularly interesting. On the one hand, science arrived in the American university at a timely period in our national development as a world power. The other contrast was revealed as government and private, mission-bound funding sources fueled the development and blazed the trail toward the Corporate University. Thus, science arrived to open a path toward the future, and government and private funding arrived with their controls and emphasis on the marketplace.

In his essay on the American land-grant system, Carter (1986) enumerates these historical influences. What follows are summarizing statements from his writing.

Experimental science in the university did not arrive at once, but was born in a struggle, holding on tenaciously but tenuously for hundreds of years before finally taking hold. The experimental method itself is ascribed to Francis Bacon (1561-1626) [although there are antecedents, such as Robert Grosseteste of Oxford (Cobban, 1988)]. Bacon's approach to learning threatened the staid university and the general public, as it brought into question the accepted norms of those times. The differentiation of fact from myth was a threat to an authority largely based on religion and superstition. Experimental science did not appear in the American university until the land-grant concept was born.

\section{The Land-grant Act of $\mathbf{1 8 6 2}$}

The land-grant concept is truly American at its base. It expresses the best of the American spirit, engendering a society in which education was to be for all, where industrial strength was emerging, and where land and resources were without limit. The public recognized that the traditional education of Europe did not meet the needs of the American energy. for exploiting opportunity. George Washington argued in 1790 for a national university (Flexner, 1970) and Thomas Jefferson was committed to education and was instrumental in establishing the Univ. of Virginia (Malone, 1981). The need for technically trained men to manage the industry and agriculture of America was insatiable. These forces all led to the passage of the LandGrant Act of 1862 during the Civil War.

Soon, the forces that shaped the Land-Grant Act of 1862 gave birth to gradual control by government and private money seeking shortterm gain via university research. We began, with this marvelous legislation, to shift the emphasis away from that of the classical education to that of training technicians for the American marketplace. In so doing, America gained the management, product development, and leadership skills to run the machines of the marketplace. But as the technical side of the equation was emphasized, we diminished, if ever so slightly at first, the other side of the equation-the humanities and a classical education. Though a pivotal aspect of American success in the marketplace, the Land-Grant Act of 1862 was not itself perfect. Not only did this system fail to address the needs of women, but it also paid lip service to African Americans by the enactment of the second Land-Grant Act of 1890. In that legislation, education for African Americans was provided for in a manner lacking substance, and it bolstered the inherent inequity of segregation.

Because the very acceptance of the landgrant concept ensured our road to the Cor- porate University, I borrow directly from a summary of the Land-Grant Act of 1862 as abridged by Carter (1986).

Be it enacted. . . that there be granted to the several States, for the purposes hereinafter mentioned, an amount of public land, to be apportioned to each State a quantity equal to thirty thousand acres for each Senator and Representative in Congress. . That all moneys derived from the sale of lands aforesaid by the States. . shall be invested. . . and that the principal thereof shall forever remain unimpaired: Provided, That the moneys so invested shall constitute a perpetual fund. . and the interest of which shall be inviolably appropriated, by each State. . to the endowment, support, and maintenance of at least one college where the leading object shall be, without excluding other scientific and classical studies and including military tactics, to teach such branches of learning as are related to agriculture and the mechanic arts, in such manner as the legislatures of the States may respectively prescribe, in order to promote the liberal and practical education of the industrial classes in the several pursuits and professions in life.

The Land-Grant Act of 1862 appealed to the mighty forces at work in America. The states could maintain some autonomy, industry and agriculture could acquire technicians, and the landless could acquire land. Interpretations of the act were many. The general public was slow to take advantage of opportunities in the land-grant system, but politicians, many churches, industry, and agricultural influences were paramount. Within these new land-grant universities battle lines were immediately drawn, lines that exist to this day. These battle lines are more tenuously drawn today, as the balance between them has been tipped-if not completely overturned-in favor of technical training and information for sale in the marketplace. These eventualities should have been expected, since the land-grant university was formed to act on and anticipate immediate human needs rather than to investigate the great questions regarding the human condition and the meaning of life. There were no institutional safeguards to maintain a balance between classical education and technical training, and, as a result, classical education was overcome by the needs of the marketplace. The vase representing a classical education has been smashed with the hammer.

As the land-grant universities moved toward maturity, privately funded colleges and universities also continued their development. A prominent private university can be found in most states. These were endowed by individual and family patrons. Currently, costs for universities have escalated so much that private universities depend more on alumni than on the wealthy patrons of the past. In fact, private universities also face a perilous future, as they too must balance marketplace realities against educational goals. The his- 
tory of private universities deserves more attention, but I have deliberately "flattened" this part of university history to accentuate the current dilemma we face in the land-grant university. Both land-grant and private universities compete in the marketplace, although the road taken by the land-grant universities may have been more direct.

All life is chemistry. Components on one side of the reaction equation combine to form something on the other side. You lose something to gain something. Nothing is stable in combined form. Degradation follows combination. Entropy rules. The product resulting from the chemical reaction of the landgrant system formed something of immediate use to the public, but I assert that this utility has been accomplished at a cost that threatens the very core of the university. This core rests on transmitting human values, on creating knowledge with wisdom, and on generating information with conscience.

Perhaps the most insidious aspect of outside pressures on the university has been their effect on academic freedom. Academic freedom is a continually developing concept that must be jealously guarded and attended to in order to maintain a true university. In contrast, academic freedom may not be seen as critical for maintaining a productive Corporate University. Indeed, academic freedom can be seen to hinder activities focused on the marketplace. I believe that-without academic freedom there can be no such thing as The University, which will be described later.

\section{ACADEMIC FREEDOM}

\section{Why academic freedom?}

Freedom of expression has been a continuing need within the human psyche for as long as we have records. This need for expression is revealed in many forms, from music and art to physical movement and personal utterance. Such need for freedom has been much in the news and on our minds with the changes in Eastern Europe, the Soviet Union, and South Africa. It is the preservation of freedom of expression in its many forms that underpins the absolute value of a university to a society. If we are not going to argue for freedom of expression in the university, then the issue is closed: the Corporate University and its marketplace mentality win.

I believe that the university should be a citadel with a soul where scholars are in contention about the nature of the universe and of human beings, where concepts, ideas, and intellectual discovery are the common currency. To achieve this, freedom of expression must be the norm. Whatever we are doing in our society currently will be transcended. Therefore, we must assemble and sustain an evolving procedure for integrating knowledge currently, and for adaptation of future knowledge. We can achieve those goals within the context of the university where ideas are challenged in open debate. In the field of education, this notion of free expression has become known as academic freedom, a concept that has developed gradually over the 900 -year history of the university.
Most of the formative action toward defining academic freedom took place in the 19th Century, with Germany leading the way. The concept has been adapted in America over the last 100 years.

\section{Academic freedom in America}

Considering our national doctrine, one might have expected academic freedom to be a given in America. In fact, it has not been. The underlying principles of our government are set forth in the Constitution and Bill of Rights. The First Amendment to the Constitution states:

Congress shall make no law respecting an establishment of religion, or prohibiting the free exercise thereof; or abridging the freedom of speech, or of the press; or the right of the people peaceably to assemble and to petition the Government for a redress of grievances.

The terms of the First Amendment are lofty indeed. But while the amendment buttresses academic freedom, it has always been given political interpretation. The amendment was given early tests during President Adam's administration (1796-1800), when the Alien and Sedition laws were enacted. These laws made a mockery of free speech, and so they were repealed during President Jefferson's first administration (1800-1804).

Metzger (1955) provides a development-of the rich history of academic freedom. He traces the subject from its possible emergence from Plato to its confirmation in America by the start of the 20th Century. The evidence presented by Metzger (1955) shows that changes in attitude regarding academic freedom have been gradual. From 1800 until about 1850, the church ruled our universities. Those universities were places where the past was given emphasis and where discipline of students and faculty was the first order of business. Faculty in those universities were often dismissed for supporting certain political candidates or ideology. Though President R.H. Bishop of Miami Univ. of Ohio argued against slavery with the Presbyterian councils directing the university, he did not dare associate himself with the anti-slavery student groups on campus at that time. Even though the First Amendment to the Constitution said otherwise, free speech did not exist on such campuses. America, the nation whose formation truly expressed the results of the Age of Enlightenment, failed to carry those precepts of free speech to its universities. On campus, a diminishingly small amount of science was presented in a cramped style, and no research was conducted. Scientific ideas were verified only when morally advantageous. Universities of that time protected a doctrine-biased authority, where paternal attitudes were applied within a moral framework. In the classroom each fact was enlisted to support providence. The atmosphere must have been dull and stifling.

In the latter half of the 19th Century, at least three forces of change provided the template for a new version of academic freedom in America: the Land-Grant Act of 1862, Darwinism, and the education of American students in Germany (Metzger, 1955). The Land-Grant Act fueled the nation with technically trained minds to work for agriculture and industry. The large number of students who enrolled, and their energy, provided the impetus to revise the old university system and develop the new land-grant universities. It was a time of change, a time when some professors grasped the opportunity for open expression. These few professors who ventured forth with open expression paid a high price: ridicule and loss of faculty position (Metzger, 1955). Even so, a trend began. Across the nation fewer university presidents and trustees were from the clergy, and doctrinal moralism was not an absolute requirement for truth.

Darwinism started a raging debate between two communities in our society. One argued for evolution from the strength of experimental and observational science. The other argued for creationism from the strength of Biblical sources and religious morality (that this debate continues today is a bit embarrassing at this juncture in our intellectual development as a nation). Darwinism planted seeds of discontent in the expanding landgrant university when those many flexible young minds entered the arena of higher education.

At the same time, more than 9000 American students were being given an advanced education in German universities. Most of the students who studied in Germany did so in the latter half of the 19th Century. In Germany, they were trained in arguments for science, the scientific method of investigation, and the concept of rigorous testing of ideas. These students were imbued with the attitude that science in the university was a life of seeking truth, not a life dedicated to fabricating products for sale. While German professors did have freedom of inquiry and teaching with little administrative interference, they did not have those freedoms outside the university. As citizens in Germany, such professors were confronted with the same restrictive political doctrine as all Germans were.

The American scholars who returned from Germany were eager to combine the advantages of the German university system into our universities and within America's free political system as guaranteed by the Constitution. Here, academic freedom could be shaped within the context of the First Amendment, and with the American flavor. The resistance these German-educated scholars ran into did not come from the clergy, but rather from big business, which was by then donating heavily to American universities. In effect, businessmen had now bought their way into university trustee positions, gradually forcing their kind of efficiency onto the American university faculty. Both then and since, faculty scholarship has been rated by publications, personality rated by its docility, and services rendered rated by costaccounting. 
Formation of the American Association of University Professors

A bureaucracy was created in the university to offset these business pressures on the faculty. The intention of business was for the faculty to behave in a prescribed manner. The intention of the bureaucracy was to provide the faculty with conditions of fairness and safety. In 1915, the American Association of University Professors (AAUP) was formed. Since at that time pressures on university professors were many, one might assume that professors would have moved quickly to support the AAUP. That was not the case. The American labor union movement as we entered the 20th Century was rarely presented in a favorable fashion. To many professors, the AAUP seemed to be an effort to unionize, and, consequently, AAUP membership increased only gradually. Today there is still resistance to unionization among university professors. ManyI among them - contend that university's purpose, goals, and status as a public agency are not compatible with union activities. Further, I find the union creed often at odds with the creed of academic freedom. However, the AAUP has in fact not turned out to be a union. Perhaps because of this, the AAUP has had a positive influence on education, an influence that can be supported by most university professors.

The AAUP published a report on Academic Freedom and Academic Tenure in 1915. This report spoke for due process, tenure, and the establishment of professional competence. A strong case was made for academic freedom to underpin the university. The report expressed the belief that trustees were simply discharging a public trust and would only interfere with professorial activities in extreme cases, that professors in classroom instruction would work within certain norms that exclude using the lectures for personal propaganda, and that outside the classroom professors had the same rights as any other citizen. Over the years, the original report on academic freedom and tenure has been polished and tested in American courts of law. This process eventually led to the 1940 Statement of Principles on Academic Freedom and Tenure (Metzger, 1955), to this day the benchmark of American academic freedom.

Academic freedom as described in the 1940 Statement of Principles on Academic Freedom and Tenure threatens the bases of the Corporate University. Where short-term gain and profit margin are the goals, academic freedom is likely to be a hindrance. The mentality of businessmen and the opportunities in the marketplace grip America; the desire for short-term gain pervades all aspects of our lives. From business activity on Wall Street to politicians in Washington, D. C., only short-term thinking is evident. No one with vision seems to be part of current critical events in America. The attitude of "take and run" prevails. But what else can we expect? The Corporate University churns out technicians whose total training is the now, rather than the might-be. A sub- tle part of this process includes behavior regulation. The notion of leveling professorial behavior seems prevalent. This notion contains pressure for equality. One cannot have both equality and freedom, and if we insist on equality then we must cast out freedom. I stand fast for freedom. The university system within the lofty context to be described next must provide our nation with a longterm view, a view that is the basis for our society, a view that breathes freedom.

There is no identifiable single event or doctrine that has led to the erosion of academic freedom. However, technicians serving as professors churning out more technicians eventually have had their effect on society. The broader issues of a society are not best solved at the marketplace. They are too complex and slow in development to be bartered for coin or to be made to face the latest computer run or daily stock exchange.

Academic freedom and all of its attendant responsibility come to the fore when we try to understand nature. Answers to the fundamental questions about nature do not necessarily support ongoing religious creeds or accepted societal norms. To investigate the origin of Homo sapiens is as great a risk today as it was in the days of Darwin and Wallace. Sensitive nerves are touched when fundamental questions are investigated, no less so now than in previous times. These broader issues that form the evolving culture of society can be continually challenged by the university and its professors dedicated toward that end. Professors can only succeed as social critics if they have academic freedom, and academic freedom must come to the university from a believing society.

\section{THE CORPORATE UNIVERSITY}

\section{Background}

The development of the Corporate University created by the Land-Grant Act of 1862 underwent a major shift during World War II and thereafter. Piel (1986) states these forces of change during the war in concrete terms when he says that "the arsenal of democracy was its universities." Thus began the final rush toward creating universities where knowledge for power was purchased for competition in the world marketplace. The effect was marketplace control of the university. The pressure on faculty for results at any cost has led to fraud in some cases and in many others to frenetic research conducted by anxious, unhappy people. The leadership in the Corporate University equates more as good: more buildings, more students, and more money equate with what they call "excellence." Inevitably, though, the blame for this lies at the feet of individual professors, those of us who aided and abetted or those of us who simply stood by and let it happen.

The process has resulted in unhappy professors, unhappy students, and an unhappy public that now distrusts the university. The consequences of a system in which professors have vested interests in private industry are many. We have lost our neutrality. The public cannot believe their "experts." Shrill voices are heard on both sides of an issue, such as pesticide use, where both the proponent and opponent are paid by the marketplace.

Private industry has had another impact on university research, one reflected in the fad and fashion of the marketplace. As a result, Piel (1986) states, "funding by the health agency has notably neglected plant life, and molecular biologists are late in addressing the plant cell in a world that must feed a population of 6 billion at the end of this century." Since 1862 we have claimed that our educational system feeds the future. But is this true? Training technicians for the marketplace emphasizes the now, not the future. Training people to accomplish a specific task is not education but, rather, craft. When educated, one does not learn the skills of the marketplace per se; rather, one learns how to solve problems, how to find information, and how to reason and enumerate available options for choices. A trained technician knows how to perform a work task, an educated person can learn how to perform work tasks on the job.

Early in the formation of our university system, one side argued for developing the mind while the other side argued for pragmatism. These forces were in balance for a while, but I believe that we are out of balance now. And it is for balance in this struggle that I argue, not for one side or the other. The shift in balance occurred in the 20th Century with the major change since the 1950s. The insatiable needs of war machines for World Wars I and II set in motion an avalanche of marketplace requirements that have continued unabated since. How could we argue for classical education when democracy itself was threatened during World War II? How could we argue for classical education after World War II, when feeding and giving shelter to a destitute humanity was a greater need? How could we argue for humanitarian studies after Sputnik in 1957 when the Soviets has surpassed the United States technologically? How then can we argue for classical education in 1990 when . . .? It's time to stop making excuses.

There are always persuasive arguments for the pragmatic, for the immediate needs for any nation, but we must guard against pursuing the pragmatic at the expense of education and of the struggle with the great questions of life. In the second half of the 20th Century, we became so paranoid about the Soviet Union and the rate at which technologists were being trained there that we lost sight of our own educational values in the American university system. Money for research and buildings became available in amounts greater than at any previous time. Rapidly, we shifted from having educators serve as university presidents and chancellors to having these positions filled by glib and successful money-getters. Our university leadership shifted from men of letters, with research and teaching experience, to professional administrators, corporate executives who could acquire funds for build- 
ings, for students seeking technical training, for research funds for the faculty and a winning football team for the alumni. The rate of growth was so great that from 1950 to 1970 a new college was formed each week (Carter, 1986).

The money to feed the growing system came, and still comes, from nonprivate sources, that is, industry and government, each subjecting the university to specific controls based on its own needs. Autonomy in the university is lost as the value system changes, from that of education to that of training, from the Academy to the gilded vocational school. The university becomes another public utility. These changes in the university have shifted control from local authority to central authority, with all of its bureaucracy, vague values, and inefficiency.

\section{Reactions from the public}

As the appetite for money expanded in the university, the professional university administrators began to stay in touch with the customer in the marketplace to maintain contact with funding sources. Eventually, as faculty individually benefited from the marketplace, they too began to tune themselves to the customer. And there we are today. Evidence for faculty participation in the Corporate University at the marketplace rests in public opinion; the public has lost faith in the university and its faculty. And why shouldn't they? Such loss of faith in university faculty culminated in political action in 1974 in California. By 1982 this process led to financial disclosure laws for California faculty. Some educators had lined their pockets from the marketplace; they had become faculty for hire. By then, the public had become disenchanted by professors paid by both public and private sources.

The issue of conflict of interest among university professors, while- mainly a problem of the science faculty, is not confined to California alone. Such conflict of interest is now a nationwide concern, and the National Institutes of Health (NIH) has taken action. They have proposed guidelines that require financial disclosure for individuals supported by NIH. As well, full disclosures are proposed for their spouses, dependent children, and other dependents (Palca, 1989). Such restrictions, made necessary by the abuses of some, begin to give further control of research by government and ignite grave doubts in the public concerning professors' credibility, impartiality, and trust.

\section{Supporting arguments}

An ongoing argument by those in the marketplace in favor of the current university system is that pragmatic university training fuels a strong economy. But the data to support this premise can be difficult to interpret. Data taken from a nation emerging on the international scene may show that education quickly translates to success in the marketplace. Comparable data from a more developed nation may be less clear. For example, Williams (1967) compared expenditures for research and development programs from
1950 to 1959 , with the average compound growth rate of output per person. His data illustrate that the lower the support for research and development as a percentage of gross national product, the greater the output per person! Statistics can be used many ways, but this study is presented to suggest caution in generalizing about the absolute positive force of a university education in stabilizing a country's economy. The marketplace is surely more complicated than such a simplistic comment implies.

No matter whether you agree with my description of the Corporate University, our dilemma is clear. Most universities are big business. The physical plant, faculty, and support staff require enormous amounts of money to operate even if no work is done, just to maintain the bloated flesh. This makes it necessary to hire marketplace "moneygetters" as university presidents or chancellors. It is also necessary that each faculty member do his/her part in accumulating grants. Indeed, those who succeed in grantsmanship automatically succeed as faculty. Feeding this system takes most of our time and, tragically, most of our creative energy away from educating students. At my own university, the University of California, Davis, that highly respected institution known for its work in biological sciences, among other fields, students and their education are the lowest priority among the goals of the university.

Some may still wish to argue that the current university is an intellectual template for the future, a place with a clear mission statement of education for our young people, where the mind is challenged, shaped and excited, an institution whose graduates, though employed, remain students of life for life. But for my part, the university has lost its time-worn values and has exchanged its soul for the pottage of mere physical, perishable things.

\section{WHAT A UNIVERSITY SHOULD BE}

Faculty must assert themselves by taking a position on what a university should be. This work is far too important to leave in the hands of the undefined "they." We faculty must rethink our mission and change our educational process as deemed necessary. In this section I will argue for a shift in emphasis, away from the Corporate University. Universities may remain places where technicians are trained, but in addition these technicians should spend considerable time on those subjects concerning the great questions of life. This means shoring up the liberal arts requirement in most universities. Next, I will examine and suggest formation of a few universities, each called "The University, "where all students will pursue liberal arts degrees but with natural science and social science as component parts of a broad education. Those students and faculty at The University will be, by necessity, elitist. From the deliberations of this elite, society's template may be formed. Some may contend that a few such universities exist today. I do not agree with such a contention.
The Corporate Technical University with a shift in emphasis

I believe our land-grant universities should seek a balance between classical education and technical training for the marketplace. What is the balance? Technicians can be trained in junior colleges, state colleges, and in industry; as well, they can be trained at the Corporate Technical University, but there, in addition, the balance should tip in favor of classical education. Whether the degree sought is in political science, mechanical engineering, or biochemistry, the education should focus on the underlying principles of that subject. Those same students should also take courses in subject areas completely outside their major fields; e.g., biochemists should take philosophy and philosophers biochemistry. Some land-grant universities are currently exploring this approach by requiring about $10 \%$ of graduation credit from general education courses in an effort to broaden student education and awareness. The assessment of what is currently taking place in general education will take time. I hope it is more substance than form.

A critical component is missing from this revised land-grant university as described above, one crisply stated by Camp (1983):

I have long believed the research undertaken by the universities should be free, independent and determinately non-utilitarian. I have also believed all a university should expect from the business community is money. And all that the business community should expect from the university is to be asked for it ... The choice is clear: starve the humanities or put them on short ration, in order to feed the sciences. This choice would ultimately assign the humanities to another jurisdiction, something for later life perhaps, or to some station in purgatory between the nonessential and the obsolescent ... Thus the universities will be producing in greater numbers than they do now, the inarticulate, the functionally illiterate, the ethically sterile, the politically passive, and the morally inert ... We will be packaging people who took no English but who mastered in jargon. The literature of our language will become something to be buried among other academic toxic wastes - philosophy and history.

The infusion of humanitarian studies into all majors is a must, but until we partially free the research arm of the university from government and marketplace control, we reduce our chances for attaining the broader education of students. Instead, we will continue to churn out partially educated technicians. Stated another way, as long as professors are paid and honored more for research than for educating students, the status quo will remain. Although our professional administrators would have us believe otherwise, major American universities are research-oriented; teaching is secondary. Research patterns and goals control the university by purchasing the minds of major 
professors and their students. Major professors in the sciences answer to sponsoring government agencies and to the marketplace, not to educational goals in the teaching program nor to students enrolled in the courses. For reasons of simple self-preservation, all professors in major universities align themselves with the industrial model of "publish or perish."

Whether in the humanities or science, the evidence for scholarly work is in its publication. To neglect publication of work is tantamount to failure and inevitably leads to stagnation. This is no argument against publication. The argument is against our current canon where the act of publication is more important than what is published.

A 1985 report from the Association of American Colleges (AAC) emphasizes the problem that emerges when research prevails as the controlling factor in the professorial reward system. Professors give minimum attention to teaching because their achievement of tenure, their remuneration, and their status among their peers depend upon research excellence, not upon teaching excellence. The beginning professor who does not understand the latter will fail utterly in the university. The diminished importance of teaching in a professor's career is clear when we consider the curricula that have resulted as courses take on a fad-and-fashion adjustment to student interest, rather than. the continual honing and improvement of time-worn areas of study. The AAC report emphasizes the necessity for action in developing a rewards system for teaching and recommends a curriculum based on nine features including: 1) art, the ultimate example of creativity and freedom of expression; 2) historical consciousness, where knowledge and understanding of the past aids in our development of the future; 3 ) inquiry, abstract thinking and logical analysis, features that should be aspects of most courses; 4) international and multicultural study, in which the contrasting of cultural traditions would be developed; 5) literacy, where the joy of reading for life would be taught; 6) science, not divided into an array of subjects but a single course where an in-depth examination of science in action is taken; 7) numerical data, by which students would. deal with principles of uncertainty, data scatter, rates of change, data confidence, and graph interpretation; 8) values, which involve the capacity to make informed, moral choices; and 9) study in depth, which is necessary to understand the basic complexity upon which the major dogma of the discipline rests.

The report of this AAC committee is laudable, I wonder if any university in America has begun to examine the recommendations. Probably not, Still, individual professors can act upon the wisdom of the report by including most of these nine features in the courses they teach.

I am not arguing that we return to a former, better university. No such place existed in the past. I agree with Fulton (1986), who suggests that such thinking confuses images with reality. We only need look at former American university policy for women and minorities to put to rest any romantic notion about the past. American universities of the past were for the sons of wealthy white men and were rarely bastions for scholarly objectivity, academic freedom, or institutional autonomy. No, I do not argue for the past; instead, I argue, for what should and can be the future.

We can achieve. both the education and training described by Jones (1984):

The term "education" is difficult to define. I believe, however, that there is fairly common agreement about the attributes of an educated person. Such a person should, at the least, (1) develop analytical skills and be capable of rational thought, argument, and judgment; (2) be studied in a broad range of topics ("university'? implies the inclusion of the whole); and (3) be able to apply his or her analytical skills and rational abilities in areas already studied and in those not yet encountered.

The term "training" on the other hand, I take to refer to the acquisition of a body of specialized knowledge and skills. A university experience should provide both training and education. The awarding of a degree in a particular area implies that the training has taken place, while the issuing of a degree by an institution known as a "university" "implies that education has taken place.

The Corporate Technical University should have a value system that is widely known and a soul that emerges when under public scrutiny. These attributes cannot be sustained when professors barter in the marketplace. Yet, what does the general public expect their children to derive from a university education? I suspect most would say a good-paying job. The values I have referred to above are perhaps esoteric to the general public, yet, they are values of the greatest importance for the development of the university's soul. As science and technology are exploited in the marketplace, values are destroyed in the Corporate University. Values are of little concern to the marketplace and only appear as an after-thought. We should start with values in the Corporate Technical University, and then proceed with facts and techniques, Values should be of concern in every Corporate Technical University course. Values can be taught, and values will enliven science courses by the insertion of the improbable and sometimes insoluble. Students must learn that science cannot provide an answer to the quest for meaning in life.

A student should gradually peel back those layers of ignorance that involve prejudice and dogma and that prevent personal development. Four years at a university should result in a student's finding herself or himself. These university years must involve more than periods of learning facts broken only by short periods of escape from the drudgery of learning facts. The crushing reality of simply learning facts is revealed in a pithy paragraph from Charles Dickens' satire "Hard Times" (1972 ed.). Chapter one begins with the school governor stating:

Now, what I want is Facts. Teach these boys and girls nothing but Facts. Facts alone are wanted in life. Plant nothing else, and root out everything else. You can only form the minds of reasoning animals upon Facts; nothing else will ever be of any service to them .... Stick to Facts, sir!

Education does involve facts, but learning facts alone is not education. The development of students with a broad eduction and some training over time could free society from internal conflicts and from external suspicions that result in physical conflicts between nations. Students should be involved in controversial issues to test their beliefs; acceptance of other viewpoints is more likely when done as a classroom activity. Such classroom exercises are a reality if the university is kept as free as possible from marketplace demands while operating in an autonomous environment. As stated above, within each course the educational value system of the university must be developed. The achievement of the above-stated goals depends on neutrality, on reading widely, and on a commitment to understanding nature. It also depends clearly on professors who, free from unproductive bureaucratic burdens, may devote time for serious, stimulating conversation with each other and with students, professors who have the opportunity to make mistakes without negative consequences in funding.

How many university professors will make a single long-term significant contribution via their research? Few indeed. Most of us have a much higher probability of having a major positive impact on a single student's life. Axelrod et al. (1969) note this point as brought up by students and their parents. Both of these groups, once beyond trivial comments about the university, recognize the impact of a single experience resulting in a life-long lesson that came from a professor or fellow student. Such critical experiences are not the result of research or of courses taught by professors. These experiences derive from close and timely contact with an individual. I do not bring up this point to argue for professors and students just sitting around talking with no apparent purpose, but to caution professors against any glowing interpretation of our research and courses taught.

With modification in curricula, all the LandGrant Act universities can become the Corporate Technical Universities partially described above. The suggested shift in curriculum toward a classical education should not be too threatening to Corporate University faculty,. despite their jealously guarded turf, but it does depend on a supportive public attitude. The latter can be gained if we emphasize education rather than research money. The more difficult challenge is to form The University, which I will describe next.

\section{The University}

The student granted a bachelor degree from what I choose to call "The University" will 
not have been trained to do a specific job, but rather will be broadly educated to handle the diversity of modern life. The University bachelor's degree would be in liberal arts. Those who enroll in The University but who are also interested in science and engineering would, by elective choice, gain the fundamental principles of those subjects as necessary. Later, by individual choice, such subjects would be studied in-depth in graduate school at any one of the many Corporate Technical Universities throughout America. All bachelor degree students would gain understanding and application of mathematics. They would learn about the physical laws that rule our universe and about the theoretical viewpoints on how the universe came to be and its future course as described in the laws of thermodynamics. Students would learn how science is developed through problem description, hypotheses development, and testing of hypotheses with definitive experiments. Science would be taught as a tool for testing ideas, as a means of collecting knowledge that has been subjected to much contention, before gradual acceptance. The scientific approach would be learned so that linkage of information and testing of ideas would become routine. These students should be challenged with devising other means for testing ideas and they would know that science and use of the scientific method for investigation cannot explain everything. Perhaps one of the most critical areas that these liberal arts students would learn involves the laws of probability and chance. Here they would engage in statistical testing, become acquainted with coincidence as a part of life, and learn of risk analysis.

Ideally, such students would grasp the literature of philosophy while at the same time learning that biology exists in a physical world where nonlinear, far-from-equilibrium processes operating in an open system exert feedback control that maintains the peculiar kind of order we call life. Such students would not be threatened by the Second Law of Thermodynamics or by the notion of chaos. Such students would be a positive influence in attempts to bring order to a world that wobbles between idiocy and ignorance. Such students could begin to exert control over our 20th Century technology that has run amok. Such students would have values derived from their university education, they would take up the high ideals that are the soul of a university and understand that knowledge does not spring solely from the western world, that knowledge is conditioned by the culture from which it springs.

The University would provide many of the leaders in areas of science, politics, and those hired to administer private and public agencies. The education of these leaders must be of sufficient breadth and depth to correct the problem described by Ashby (1972):

Our system of higher education, which has been the formal apprenticeship for most of the technological goal-setters ... gives no training in two essential areas: for politicians and administrators there is no training in how to use the inputs of science in the making of political decisions; for scientists there is no training in how to give due weight to non-cognitive considerations in choosing extrinsic goals for science. When, for example, do the results of science justify political action? Should cigarettes be as illegal as pot? Should women in overcrowded countries be obliged to take the pill under risk of punishment, as some units of Australian soldiers were obliged during the war in New Guinea to take Atebrin againsnt malaria? Should air-lines pay through airport charges for the noise pollution they cause, and the proceeds be used to provide double-glazing in all homes within ten miles of the runway? These are the sorts of questions which cannot be answered within the framework of science alone or politics alone. Neither the scientist nor the politician can get from our system of higher education an expertise for dealing with such questions.

The University would emphasize the study of philosophy and its supporting structure in the humanities. One approach, with its recognized short-comings, involves study of the great books (Bloom, 1987). Here, the emphasis pertains to central questions about the human condition, nature, and this unfathomable journey we are on. Such questions are only partially answered, if at all, and never completely. Each generation must ask such questions anew in order to test the culture evolving from society. Such great and fundamental questions cannot be answered in natural science, even when we biochemically define every physical aspect of life. Constructing a fail-safe artificial heart will not explain why we are here, the meaning of truth, absolute juistice, or the human need for music, art, and literature.

To succeed in attaining the stature I envision, The University must develop a value system and have a soul. The University value system should rest upon 1) neutrality and independence, 2) reading as a way of life, 3 ) a continuing attempt to understand nature, and 4) professional integrity and devotion of professors. The soul of The University, which derives from its struggle with the great questions of life, is the benchmark that the society can look to when all else seems in disarray. These features of The University are fragile; they can no more withstand the assault of the general public and the marketplace than a porcelain teacup can resist a hammer blow. The University will exist in the same manner as paper money: by the faith and good will of the general public. It is a tenuous proposition at best.

The University must gain public acceptance, but it must do so without sacrificing a value system in the marketplace, for the goals here are independence of the mind and freedom of inquiry. The medieval university was mind-shackled by the church, and today we are mind-shackled by the marketplace. Intellectual independence continues to threaten the general public. Ideas that run counter to the norm are rejected, and individuals expressing those ideas are themselves likely to be threatened. In this regard we would be remiss to blame rigid thinking on the general public only; I have found some university professors to be more intractable and less amenable to new thought than many in the general public. Independence of mind will provide insight into our future, without which we will simply embellish the past.

The independent mind is not easily retained when employed by the marketplace. Thus, incorporation of any aspect of the marketplace into The University must be done with great care. Payment for work rendered can prejudice the results. What is linked directly to the independent mind is neutrality, and one is not neutral when under contract for services rendered. How can students or the general public turn to The University for neutral opinion when it is under the grip of the marketplace? The University's value system and soul that I describe can present valuable judgments of lasting merit, but only when expressed by independent, neutral minds.

Classical Newtonian mechanics put a lock on scientific thought by asserting that all natural processes could be described by linear, deterministic relationships, dismissing all other ideas, Starting in the 19th Century, disagreement surfaced; a few scientists stated that biology existed in a nonlinear, far-fromequilibrium, open system, where feedback control dominates. Scientists expressing those thoughts were rudely dismissed until recent times. Now, nonlinear thermodynamics is one of the most active area of physics research, and from this research the notion of chaos has evolved. Keep in mind that even Einstein was arguing against nonlinear thermodynamics, a sobering point as, rightfully so, we revere Einstein's work and realize that he too had to overcome peer rejection of his Theory of Relativity. Yet, even the innovator and genius among us may suppress challenging information unless we maintain a vigil on independence of the mind and neutrality.

The second factor to ensure value development in The University requires reading. Printed matter and reading have given the university its history in development; even though a scholar dies, the writing of that scholar remains. The style of our writing demands neutral presentation of background on subject matter before offering opinion on interpretation of experimental results. Yet each of us starts with a driving bias, as I have for this essay; it is difficult to be clear, forceful, and neutral all at the same time. And there rests the tenuous balance between presenting an uneasy truth and presenting evidence with interpretation. The difficulty of that assignment reveals the best and worst in all of us.

But what is the status of reading in these times of visual and electronic communication? Competition for and constraints on time have taken away from reading, until now we have the Executive Summary. Partial understandings are derived from these Executive Summaries (or from the few that are wellwritten) but still, they remain second best to reading the complete text, a desperate at- 
tempt to compete for audience attention. Our society and some of its professors lack the detailed reading necessary for complete understanding. The consequence is partial understanding or even misunderstanding. Perhaps I err by emphasizing only books and their complete reading in The University; apparently, Socrates wrote nothing and successfully communicated his thoughts verbally. The printing of books was certainly a major factor of change and the release of many from human bondage. We may now be in a post-print culture with new and better means for communication of thoughts and ideas. We have visual and audio forms of information transfer; these can be powerful indeed and potentially add to our methods for storage and retrieval toward attaining knowledge. Nevertheless, reading provides for study in-depth of ideas and concepts, something often missing in this era of 20 second sound-bites.

The third factor contributing to The University value system requires an understanding of nature, including the nature of ourselves, mankind, the world. This, in the broadest sense, might be our most noteworthy goal in The University. Here we put into full force the necessity for the neutral, independent mind and for reading the collected writing about nature. To understand nature means to question available information and to devise ways for finding what has always been there. The fundamental questions do not yield easy answers. What is the origin of the universe? From what did we evolve? What is our purpose? What is our destiny? How does the brain work? How can we cure cancer? How does a plant flower? Such questions are endless and their open investigation involves risk, the risk of making mistakes or of overturning dearly held ideas, thereby incurring the wrath of those who guard dogma. Currently, research activity in the Corporate University and its marketplace does not allow for mistakes. Supported research in the Corporate University is based on previous evidence for success and is oriented toward short-term products. Of course, such projects may be of the highest quality and of great necessity, and many contribute to our fund of knowledge; Yet, I argue that such projects should be done in The Corporate Technical University and not in The University. The University should pursue the understanding of nature rather than the development of salable products.

The fourth factor listed to sustain value and develop a soul in The University is time. University professors in our traditional arrangement do not have time. They are constantly reacting to pressures rather than acting on inspiration. The trivia and minutia of a professor's day are legend. We are in an age of communication, and the professor seems to be in the eye of the communication storm. The result is less communication with fellow professors, less communication with students, and virtually no communication with self. I believe that this threatens our culture. The culture I refer to is as defined in The American Heritage Dictionary as follows: the act of developing the social, moral, and intellectual facilities through education. These features of The University culture will not occur by simply placing students in residence halls, where they sleep and eat, or by having those students attend classes where knowledge is transferred, or by seeing that those students participate in social functions. The successful transfer of culture requires meaningful contact with its advocates, university professors. In the current Corporate University, professors do not have time for steady contact with students. In fact, if a nontenured Corporate University professor of today seeks steady student contact and thus spends time away from marketplace research, dismissal is the consequence because of lack of publication. If The University I describe should be the center of a society's culture (and I believe it should), then its professors must exhibit culture and must have time to share that culture with their students. The question now is, do any of us (professors) have culture or are we simply technicians cloning technicians for the marketplace? If the answer is the latter, then where will the professors for The University come from? I will offer an answer to that question in the epilogue.

In spite of the evident bias and various forces shaping the historical university, it has been a wavering cultural center for society. The university has weathered the machinations of feudal kings, the imprisonment of the mind by the church, and the machine mentality of Newtonian physics. It withered some under the grinding pressure of the Industrial Revolution. But in this the Information Age, the university finally may have lost its grip on culture. The Corporate University in the marketplace has no time for culture. Of what value are social, moral, and intellectual attributes when the marketplace demands that the Corporate University work on the Strategic Defense Initiative? We cannot turn down such large sums of money, can we? The University must step into the gap left by neglecting the development and maintenance of our culture.

Those who are proponents of technical training over general education argue from pragmatic bases, but I counter that classical education as described for The University is more pragmatic than training. Those trained to perform a specific job will not have the flexibility to meet the changes and challenges that are with us today, let alone those of the future. But a classical education as described here provides the breadth of background to address the problems of these changing times. Even, and perhaps especially, those at the $\mathrm{PhD}$ level will need breadth to meet the demands of future opportunity, or they risk being left behind in the wake of change. The skill to determine the structure of DNA or manipulate genetics is not enough. We need to have struggled with the great issues to understand the questions of morality surrounding genetic manipulations of molecular biology. Those who say that biotechnology presents no moral dilemmas or has no social consequences are doing the whole of science a disfavor.

\section{EPILOGUE \\ Problem restatement}

The land-grant university system was a splendid and novel idea in the 19th Century. The thrust was to benefit all members of society, not just the sons of wealthy families who could afford the costs of expensive universities. The land-grant mission was a first: the tripartite of teaching, research, and extension. Formula funding and strong leadership maintained the mission of the landgrant university. The faculty were aware of and generally accepted the land-grant mission. In time, societal problems became the research problems of the land-grant faculty.

But the events of the 20th Century have eroded the land-grant mission. In some cases, grant funding represents the effective spending money for research programs, and this grant funding has had the power to redirect research away from societal problems and applied studies. A concurrent aspect of grant funding success demands that the grantee be more concerned with peer approval and therefore less concerned with societal problems; research and publication are viewed as isolated and self-fulfilling activities, and extension is viewed in uncomplimentary terms. Teaching is now moving away from the landgrant university to more flexible and responsive locations. The land-grant faculty is on the brink of becoming an assembly of remote and uncaring individuals who seek national reputation over educating students. (Of course! They must or be fired.) Cooperative extension is expected to plug all the gaps in the land-grant system, but it is collapsing under the burden of these expectations, all too often heaped upon them by inept and effete leadership.

The current leadership of the land-grant universities daily pursue higher ranking on the list of the top 100 universities as measured by research and development dollars. While their counting may be accurate, they have no assessment of quality, and this approach is crass and destructive to the university.

This nation does have a continuing need for technicians, and the Corporate Land-Grant Universities do train technicians for the marketplace. But as currently done, the tug-ofwar between training technicians and educating individuals is out of balance. Further, at a time when America can least afford it, technical training is maintaining the past for short-term gain. The current process churns out people who have good memories, people who are conformists and who lack intellectual ingenuity. We need to reorder our main structure in the university, starting with our mission statement. The clarion call of this mission must ring out by emphasizing education over technical training, emphasizing the underlying bases and theories over those of a saleable product, emphasizing humanism over exploitation and integration over infinite division. We must argue for a university with defined values and mission statements, substance and soul, over a prag- 
matic university, where absence of purpose is evident and where values rarely exist.

The seeds for doing this are planted. Amidst all the colorful external display and youthful shouting, some of the students of the 1960s were requesting knowledge and relevance. Instead, they were given permissiveness with neither purpose nor content. Of what value was that permissiveness? Women through various means asked for equality. As it apparently has turned out, they were told to be like men. In such cases and many others, we have bungled great opportunities to pursue knowledge over product, opportunities for neutrality, with independence of mind over gender restrictions for membership in the club. Was our answer to the idealism of the ' 60 s the greed, rampant materialism, social bankruptcy, and jingoism of the '80s?

Perhap these two movements spinning out of the 1960s, better than any other, reveal the state of the Corporate University. The quest for knowledge was dodged in committee actions and the request for equality was "solved" by the quota mentality. But what else can we expect from the faculty who make up the Corporate University? We are too busy chasing money to pay attention to side issues. Our personal assessment and success hinge on research, not on other issues. I charge that information is developed at the Corporate University without conscience and that the Corporate University physical plant is worshiped more than its educational purposes. Even the prospects of the patent have entered the Corporate University arena. Here, both the professor with the successful patent and the university have a lucrative carrot to chase. But the patent has its own set of caveats: changing research focus toward financial remuneration, decreasing openness in results, and increasing the kind of secrecy that leads to fraud. We can turn these events around. For a university to enjoy continual success constant tending is required. We now must turn to the business of tending our universities.

\section{What can-be done?}

America has burst out of the Industrial Age and into the Information Age. The land-grant universities that played a magnificent role in the Industrial Age seem unaware that we are in the Information Age. We are providing old solutions to problems and ignoring other issues of societal concern. We must take the tripartite mission of teaching, research, and extension and rethink its application to the Information Age. This does not necessarily mean trashing our successful engagements in engineering and agriculture, but rather rethinking those endeavors coupled with the new challenges of the Information Age. Now more than ever, the education of our population is paramount. It is our only hope of extracting useful citizens from the paved jungles of our nation. We must capture these young minds before they are smashed by nervous, jangled, disfigured masses teeming in hopeless conditions. Both the "yuppies" and the homeless are social products of the same process.
I expect our university system to be neither a camp for social revolutionaries nor a trade school. Yet I do believe we can take our tripartite mission that has been so successful in agriculture into other facets of American life. Nationally, we have expressed great concern about the education of our youth in elementary and high school. Efforts to shore up teacher qualifications have been developed by the National Science Foundation through fellowships, by community colleges offering instructional programs, and by high school recertification programs. Each has been helpful. What I suggest now is that we focus on the problem of educating our youth by using the landgrant university tripartite mission. I ask that the land-grant universities take this proven mission to the elementary and high schools. In this application, we can lead the continuing education of our teachers as we have done for years in agriculture. As in the case of our successful agriculture example, we must go to the teachers, to where they work. For example, we can take the subjects that are taught in the school and conduct refresher courses and seminar sessions much like those presently conducted by cooperative extension in agriculture: professors teaching teachers. The goals in this extension program taken to elementary and high schools would be: 1) updating teacher subject expertise and 2) continually exposing teachers to the excitement of learning. A teacher interested in subject matter has a better chance of arousing young pupils' interest in learning. Education does not stop with $\mathrm{BS}, \mathrm{MS}$, or $\mathrm{PhD}$. Education is a continual process for life. The land-grant tripartite mission could take up this challenge: education for life,

All learning is hard work and progress is slow, but the personal rewards can be precious. We must infuse into the teachers of elementary and high school pupils the joys of learning. We can do this with our tripartite approach. By going to the teachers with our time-proven extension programs, our outreach to their community, we will succeed and they will succeed.

Next, let's begin turning out educated technicians as a mission in the Corporate Technical University. In their development, let's strike a new balance between classical education and training. To be sucessful, a part of this new balance in the Corporate Technical University calls for divesting ourselves of some of the support from government and industry. Such a suggestion may place us on the lunatic fringe, but the fact are hard to argue against: the universities are not now in control. Further, nonprivate support of universities subjects them to constant political upheaval. Both government and industry support vary with the times. Both reflect short-term political intrigue and neither is dedicated to education but rather to the marketplace. Stability is the ideal mark of the privately endowed university. Certainly these private universities have their periods of stormy financial matters, but they have not suffered the roller-coaster consequences of government- and industry-based universities of the marketplace. Let's work with the American public on this mission. We can enlist their support for the educational goals I have described. While the general public does not have the background to understand research, they do understand clearly presented educational goals and teaching.

The changes I suggest would result in a stormy period for the Corporate Technical University, but these changes can be accomplished. The overall long-term incentives for faculty, students, and our society make these changes possible and the adoption of the nine factors previously abstracted from "Integrity in the College Curricula" a reality. In the context of such adjustments, it is even possible for the Corporate Technical University to regain the principles delineated in the 1940 Statement of Principles on Academic Freedom and Tenure.

Attaining the goal of establishing The University is more difficult than adding new goals to our tripartite mission or striking a new balance between classical education and technical training in the Corporate Technical University. To achieve The University, a place with values and a soul, whose professors with knowledge will not abuse the power of that knowledge, and whose research is risk-oriented, will require a select faculty of unusual standard. Most of us will not qualify for such status. But the quality of culture that I expect from The University does not rest on having many professors; rather, it rests on those few with substance. Remember the disproportionate influence that German universities had in the 19th Century. Those scholars influenced the world and did so with fewer professors and students than are present at any single, prestigious, large American university of today! I believe that America is willing to fund a few private universities as I describe. A few is enough. Over 100 years ago, H.A. Rowland described the need for a few quality universities in sharp terms. At the time of his address at the 32nd AAAS national meeting, there were about 400 U.S. colleges and universities. He said, "The whole earth could hardly support such a number of first-class institutions. The curse of mediocrity must be upon them to swarm in such numbers. They must be a cloud of mosquitos, instead of eagles as they profess" (Piel, 1986). To this day, the need for the noble institution is not one of quantity but of quality. The faculty that makes up The University will flock from around the world. The incentive will be to obtain the position of a lifetime. In The University, stability would evolve from private funding and the faculty would not be in the business of solving society's day-to-day problems. Rather, it would constantly test its intellectual template. The template described in its mission statement rests on neutrality, intellectual freedom of the mind, and the study of nature by professors who have the necessary time and who provide a culture for the greater society. This is The University with values and an emerging soul. By removing government and industry funding. The University 
would achieve autonomy and remove the gag that is the silence of reporting demanded by industry and government-sponsored defense research.

Frankly, I would hope such a university system could be ignored by the greater public until they could cope with its intellectual energy. The latter is possible, providing university support was from private sources devoid of political intrigue and marketplace needs. In this university system, all would be welcome to acquire knowledge of use, whether government, industry, or individual. The knowledge would not be for sale, rather it would be free. No power would accrue to The University as it gave away knowledge. For the free exchange, The University would be granted the absolute reign stated in the First Amendment, academic freedom, the right to risk in discovery, and an open society of scholars without regard to gender, race, or creed. Truly a society of explorers.

When we achieve the status of The University, our current low standards concept would be buried as the faculty and student body would be of rare timber. "Public or perish" would cease to exist. Of course, a certain portion of that faculty would continually fail to meet those lofty standards, but it would be an increasingly small number. Why? The pressure to measure up would be too great in such a faculty for its professors to accept anything less than their best personal intellectual effort.

In neither of the university systems described do I argue for a life of contemplation nor a class-structured society to become a part of the systems. Our society cannot afford, nor will it currently condone, such an institution. Individually, we must contribute to society and without a class structure. We need thought and we need action on that thought in society. Currently, some of our professors report to each other for the purpose of impressing each other. The action is internal; instead it needs to be external, extended to the-public. As well, action without thought is destructive. We must integrate our technical specialties. Our students must learn how to extend information and how to integrate technical specialties into the fabric of our society: I firmly believe that both the Corporate Technical University and The University described can be achieved. The time is right. The public is dissatisfied with the current Corporate University whose professors are for sale. Certain of our universities that are already privately supported could be marked to become members of The Uni- versity. The land-grant universities that currently train technicians could continue to serve that vital function for the marketplace but with a new balance between classical education and technical training and to do so without pretense. The question is, who is willing to fund The University? Is there even one person out there?

I contend that the time is right to make major changes in our American universities and that the American society is ready for these changes, even eager to have a public institution in which they can express their pride. However, the changes I argue for will not occur as long as our universities are in the unrelenting grip of government and the marketplace. At the beginning of this American nation, the founding fathers chose to separate church from state. That decision was taken to remove the grip of the church on government as seen in Europe. Now I believe the time has come to separate government from university education. Am I asking for government financial support without control? Yes! The educational system must be supported by the people but must be free from the control imposed by research-forproduct and the short-term profit motive. Those professors who wish to conduct research-for-product should do so in the research units of private enterprise. Thus, private enterprise should conduct its own profit-motivated research rather than paying universities to conduct the research for them.

I now address the faculty. Are you ready for change? Do you support the current drive in universities to force young faculty to become monoclinal professors who will attract large grants and qualify for the National Academy of Science? I hope you will fight for diversity, diversity that allows for professorial success in public service, teaching, and research. I am not suggesting that we discourage entrance into the National Academy of Science, rather, I am arguing for the inclusion of other avenues for professorial success that are as acceptable as this particular one.

The great French foreign minister Tallyrand said that when you make it in a man's best interest to do right, he will do right. I agree. We faculty can change the university system by acting now. Our self-interest lies in rewarding broad diversity in the faculty equally, be it public service, teaching, or research. The studies outlining the change needed, such as "Integrity in the College Curriculum," have been made. In broad terms we faculty know what to do. Both the Corporate University and The University must be places of ideas and contention over those ideas. Private industry must be the place for exploiting those ideas. I therefore challenge you to ask yourself the following question: Are you satisfied with your university system? If not, then you must define the problems you see, develop solutions to those problems, and put those solutions into action.

\section{Literature Cited}

Ashby, Eric. 1972. Science and antiscience. Soc. Rev. Monogr. 18:209-226.

Association of American Colleges. 1985. Integrity in the college curriculum. Assn. Amer. Colleges, Washington, D.C.

Axelrod, J., M.B. Freedman, W.R. Hatch, J. Katz, and N. Sanford. 1969. Search for relevance: the campus in crisis. Jossey-Bass, San Francisco.

Bloom, A. 1987. The closing of the American mind. Simon and Schuster, New York.

Camp, D. 1983. Liberal arts in danger of dying lonely death. Conference report: business and the universities. Financial Post (14 May).

Carter, J.V. 1986. The land-grant system: How appropriate to the current environment? HortScience 21:190-194.

Cobban, A.B. 1988. The medieval English universities: Oxford and Cambridge to c. 1500. The University of California Press, Berkeley.

Dickens, Charles. 1972. Hard times. Imprint Society, Barre, Mass.

Flexner, J.T. 1970. George Washington and the new nation: (1783-1793) Little, Brown and Co., Boston.

Fulton, M.E. 1986. Historical commitments in new times: the restructuring and reorientation of teaching and research. In: W.A. Neilson and C. Gaffield (eds.). University in crisis: A medieval institution in the twenty-first century. The Institute for Research on Public Policy, Montreal, Canada.

Jones, D.S. 1984. Letter to the editor. Chem. and Eng. News. 9 Apr. p. 5.

Malone, D. 1981. Jefferson and his time: The sage of Monticello. Little, Brown and Co., Boston.

Metzger, W.P. 1955. Academic freedom in the age of the university. Columbia Univ. Press, New York.

Palca, J. 1989. Conflict over conflict of interest. Science 245:1440.

Piel, G. 1986. Natural philosophy in the Constitution. Science 233:1056-1060.

Rogers, W.P. 1942. Andrew D. White and the modern university. Cornell Univ. Press, Ithaca, N.Y.

Williams, B.R. 1967. Technology, investment and growth. Chapman and Hall, London.

Winchester, I. 1986. The future of a medieval institution: The university of the twenty-first century. In: W.A. Neilson and C. Gaffield (eds.). University in crisis: A medieval institute in the twenty-first century. The Institute for Research on Public Policy, Montreal, Canada. 